\title{
TECHNIQUES FOR PREPARATION OF PYRITE AND LIMONITE PERMINERALIZATIONS
}

\author{
WILLIAM E. STEIN, Jr., DAVID C. WIGH'T and CHARLES B. BECK \\ Division of Biological Sciences and Museum of Paleontology, University of Michigan, \\ Ann Arbor, MI 48109 (U.S.A.)
}

(Received February 12, 1981; accepted July 20, 1981)

\begin{abstract}
Stein, W.E., Jr., Wight, D.C. and Beck, C.B., 1982. Techniques for preparation of pyrite and limonite permineralizations. Rev. Palaeobot. Palynol., 36: 185-194.

Procedures are presented for the preparation of fine-polished surfaces of pyrite permineralizations, and demineralized thin-sections of limonite permineralizations. A major new feature in both procedures involves the re embedding in plastic of individual cut sections in order to promote stability of the often crumbly material during further preparation. Pyrite sections are kept flat during polymerization of the plastic by means of a binder clip press. The technique for limonite permineralizations is characterized by the use of plastic not only for re-embedding individual sections but also for adhesion of sections to glass slides. Following this, sections are ground thin and demineralized with hydrochloric acid. We strongly recommend use of the thin-section technique for all studies utilizing limonite permineralizations because this method permits a much greater resolution of detail than is possible with other methods.
\end{abstract}

\section{INTRODUCTION}

One of the major problems in studying the internal structure of Devonian plants has been a lack of consistently reliable techniques for recovering the maximum information from fossils permineralized by pyrite (iron sulfides) and limonite (hydrated iron oxides), the most common forms of preservation in these plants.

Pyritic specimens have contributed to paleobotanical knowledge for at least half a century. One of the early contributions was the study of the internal structure of Aneurophyton germanicum from the Middle Devonian of the Rhineland by Kräusel and Weyland (1929). Soon, thereafter, studies by Arnold $(1935,1940)$ and Read (1938) of pyritic Middle Devonian axes (Iridopteris, Reimannia, Arachnoxylon, Triloboxylon and others) from New York further emphasized the importance of this form of preservation. Only a small part of the potential information in these specimens was recovered by these early studies, however, because of limitations in the techniques and methodology employed. 
Beck's (1957) study of Tetraxylopteris provided the first clear example of the wealth of information which can be extracted from pyrite permineralizations when analyzed carefully in three planes of section. Since then, there has been a progressive increase in the utilization of pyritic specimens in analysis of the systematics and morphology of fossil plants (Beck, 1960; Carluccio et al., 1966; Matten, 1968; Stockmans, 1968; Scheckler and Banks, 1971a, b; Mustafa, 1975; Grierson, 1976; Bonamo, 1977; Serlin and Banks, 1978; Gensel, 1979; Stein, 1981; to name only a few of many possible examples). This has resulted from a developing knowledge of the chemical and structural properties of pyrite by paleobotanists, and from a growing confidence that such specimens can, indeed, produce useful, detailed data on histological features, modes of trace departure, branching patterns, and the like.

Studies of limonite permineralizations, although begun at approximately the same time, have lagged behind those of pyritic specimens in terms of the amount of information recovered even though limonitic specimens are more abundant in many stratigraphic horizons. Part of the reason for this may be due to the fact that techniques applied to these specimens have been less successful, in general, than those applied to pyritic specimens, although excellent results have been obtained in some instances (Beck, 1967, 1971; Leclercq and Lele, 1968; Fairon-Demaret, 1977; Mustafa, 1978; Scheckler, 1978).

The techniques employed to date in the study of both types of permineralizations have been quite variable and, in many cases, a method successful for one specimen has proven unsuitable for others which appear to be similarly preserved. Consequently, one of our major projects over the past several years has been to develop consistently suitable procedures for the preparation of pyritic and limonitic specimens being studied in our laboratory. We believe that the resultant techniques are superior to methods employed else where at present and, therefore, warrant publication. In general, our techniques can be divided into two types: (1) treatments of pyrite surfaces for observation with incident light, and (2) production of demineralized thinsections of limonite permineralizations for observation with transmitted light.

\section{TECHNIQUE FOR PYRITE PERMINERALIZATIONS}

The sulfides of iron are grouped here under the general term "pyrite". Pyrite is opaque, and etchable in nitric acid but not in hydrochloric acid. The oldest and most successful technique for preparing pyritic axes has been to produce surfaces polished with fine abrasives followed by etching in some cases to improve contrast. This method is generally equal to, or better than other methods which have been attempted to date. Jennings (1972) developed a polyvinyl chloride peel technique for pyrite permineralizations, the primary advantage of which was the closer spacing of observable serial surfaces. However, this method has application only with specimens containing a large amount of carbonaceous wall material. 
Heretofore, the major difficulty with the preparation of polished pyrite surfaces has been the fact that pyrite cell lumen casts often become dislodged during polishing, resulting in pitted surfaces which are difficult to interpret. Beck (1955) used a heat-activated mixture of toluene and synthetic resin (Harleco synthetic resin) for the stabilization of pyrite surfaces. However, this method requires considerable skill in applying the resin in the proper mixture, and also in surface-polishing since the resin does not penetrate the specimen. A new method of stabilization, outlined below, which makes use of a synthetic resin casting plastic, offers two distinct advantages over the earlier method: (1) stabilization is more reliable because of the uniform consistency of the plastic, and (2) the stabilizer is more deeply penetrating as opposed to being strictly surficial.

(1) Heat clean specimens to about $300^{\circ} \mathrm{C}$ on a hot plate in a fume hood. (This is necessary in order to drive off water and sulfuric acid, oxidation products of pyrite left in contact with air, since these substances inhibit complete polymerization of the plastic.)

(2) Embed specimens in plastic ("Bioplastic" - Ward's Natural Science Establishment, Inc., Rochester, New York, 14603, U.S.A.). It is helpful to apply a gentle vacuum while the specimen is in the catalyzed plastic but before it hardens in order to pull air out of the specimen which might otherwise collect along its surface during polymerization.

(3) Following polymerization of the plastic (about $24 \mathrm{~h}$ at $45^{\circ} \mathrm{C}$ ), trim the plastic block containing the specimen and cut transverse or longitudinal sections using a thin-sectioning machine equipped with a very thin blade (e.g., "Diamond Wheel" spec. D240-N100-M-1/16, Norton Co., Worcester, Mass., 01606, U.S.A.). A common thickness of sections in our laboratory is $1 \mathrm{~mm}$, although it may be desirable to make thicker or thinner sections depending on the nature of the specimen.

Occasionally, air will be trapped within the specimen causing sections to crumble during cutting. In such a case, it is necessary to re-embed the specimen before cutting additional sections. To do this, place heavily catalyzed plastic on the cut surface of the block, and subject the specimen to a mild vacuum. Following this, allow the new plastic to polymerize.

Once cut, place individual sections in a press ${ }^{1}$ since, upon drying, they often tend to curl. Sections should be allowed to dry for one or two days at room temperature, or preferably at a slightly elevated temperature in a warming oven.

(4) In order to completely stabilize sections for polishing, re-embed individual sections in plastic. To do this, first immerse sections in fresh, uncatalyzed plastic for about $24 \mathrm{~h}$. (This allows the plastic monomer to penetrate each section replacing air which, under most circumstances, is trapped inside.) Following this, remove each section and place it in a small pool of

\footnotetext{
'Our simple press consists of two glass slides $(55 \mathrm{~mm} \times 70 \mathrm{~mm}$ ) held firmly together by two large binder clips (Fig.1). (We have found a clip called "Boston clip No.3", supplied by the Hunt Manufacturing Company, Statesville, North Carolina, 28677, U.S.A. to be most useful, but any comparable clip can be used.)
} 


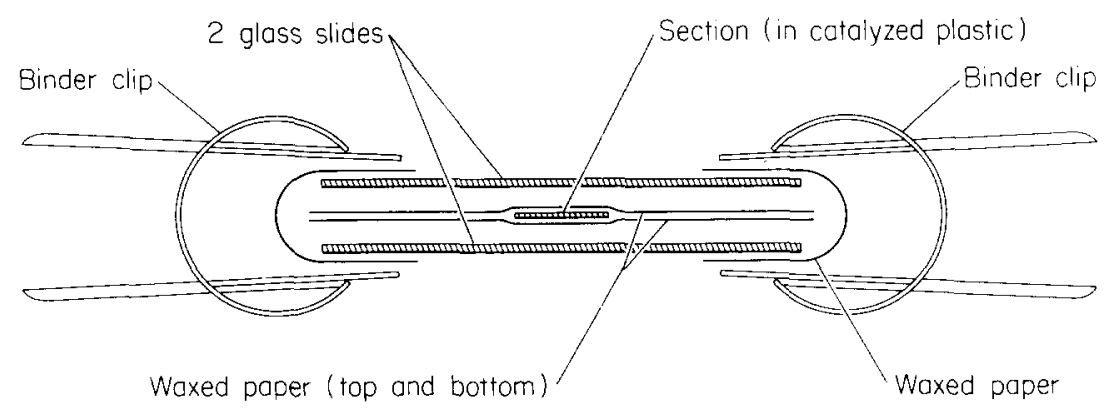

Fig.1. A simple press used to keep sections flat during re-embedding.

heavily catalyzed plastic between layers of waxed paper ${ }^{1}$ in a binder clip press (see Fig.1). Allow this to cure at $45^{\circ} \mathrm{C}$ for 24 to $48 \mathrm{~h}$. After $24 \mathrm{~h}$ it is often necessary to remove the press and waxed paper in order to insure complete polymerization of the plastic.

(5) Sections may now be polished on both surfaces. First remove the thin layer of plastic covering the cut surfaces with $\# 600$ silicon carbide abrasive ("carborundum" powder, available from The Norton Company, Worcester, Massachusetts, 01606, U.S.A.), and then polish the surfaces with $0.05 \mathrm{~mm}$ aluminum oxide powder. To improve contrast, it may be desirable to etch the surfaces with nitric acid. An etch procedure similar to that of Jennings (1972) yields excellent results. First, immerse sections in concentrated nitric acid for a period of time ranging from $10 \mathrm{sec}$ to 2 min depending upon the nature of the material. Follow this by neutralization in a concentrated solution of sodium hydroxide (about $5 M$, but exact concentration is not important) for one or two min. Then, acidify the section in reagent strength hydrochloric acid for about $15 \mathrm{sec}$ to remove brown iron oxide residues, briefly neutralize in a weak sodium hydroxide solution, briefly re-acidify in 5-10\% hydrochloric acid, and wash in water for several min. Be careful not to damage etched surfaces.

(6) Following the water wash, dehydrate and permanently mount the polished or etched sections. (In our laboratory, sections are dehydrated in a graded ethanol series, allowed to equilibrate in xylene, and then mounted in a xylene soluble mounting reagent - "Eukitt" manufactured by $\mathrm{O}$. Kindler, West Germany, distributed in the U.S.A. by Calibrated Instruments, Inc., Ardsley, New York, 10502).

\section{TECHNIQUE FOR LIMONITE PERMINERALIZATIONS}

Specimens permineralized with iron oxides can be peeled, but more commonly sections have been cut and the surfaces prepared for observation with incident light, either with (Matten, 1966; Skog and Banks, 1973; Scheckler, 1978; Brauer, 1980) or without (Leclercq, 1951, 1957; Leclercq

\footnotetext{
${ }^{1}$ Instead of waxed paper, we commonly use glassine.
} 
and Banks, 1962; Fairon-Demaret, 1969, 1980) surface etching. Etching reagents which have been employed include hydrochloric acid, oxalic acid, and hydrofluoric acid. Sometimes, the results can be very good, and the distinct advantage of this technique is that both surfaces of each section can be prepared and analyzed. Often, however, these methods produce surfaces which yield only a fraction of the available information in the specimens. Under most circumstances, better histological detail can be revealed by the thin-section method outlined below. A form of this technique was first employed by Beck $(1967,1971)$. The method given here differs from Beck's original procedure by (1) the presence of a plastic re-embedding step, (2) the use of the same plastic for adhesion of the sections to glass slides, and (3) the more complete demineralization of the thin-sections. The first two improvements promote stability of sections during grinding, and the third allows for the observation of fine structural details with the use of transmitted light.

(1) Embed and section specimens as outlined above. Limonitic specimens also require heating before embedding in most cases. (We cut sections to a thickness of between $0.7 \mathrm{~mm}$ and $1.0 \mathrm{~mm}$ depending upon the nature of the material.)

(2) After cutting, select the better preserved surface of each section and polish it using $0.05 \mathrm{~mm}$ aluminum oxide only if this is possible to do without causing the surface to crumble. Following a period of thorough drying, place the sections in fresh, uncatalyzed plastic and allow them to remain for $24 \mathrm{~h}$ at room temperature.

(3) Place individual sections in a small pool of heavily catalyzed plastic, preferred side down, on a glass slide whose surface has been roughened with \#600 silicon carbide grit. (It is necessary to frost the surface of the glass in order to attain proper adhesion of the plastic to the glass.) Each section must be pressed down onto the glass surface in order to insure that the section lies parallel with it. Place these preparations in a warming oven at $45^{\circ} \mathrm{C}$ and allow the plastic to polymerize overnight. Bent or curved sections often can be flattened during polymerization of the plastic by placing the entire preparation, wrapped in waxed paper, in a binder clip press.

(4) When the plastic has hardened, examine each slide for air bubbles between the glass and the section. If air is found in the region of the specimen, remove the section from the slide and remount. The section can be freed using a sharp razor blade after softening the plastic in tap water from one to four weeks. It is important to check on the condition of the plastic every few days since sections should not remain in water any longer than absolutely necessary. Following detachment from the slide and a thorough drying in a binder clip press, reprepare surfaces and remount sections following steps 2 and 3 above.

(5) Grind properly mounted sections to a thickness of $15-25 \mu \mathrm{m}$ using first \#100 or \#240 silicon carbide grit followed by hand grinding with $\# 600$ grit on a glass surface. Considerable care must be exercised in grinding sections to the proper thickness. Although there is variability among specimens, 
sections are usually thin enough when the limonite becomes slightly translucent under strong light.

(6) After grinding, demineralize sections in reagent strength hydrochloric acid. They should remain in the acid until no further change in the appearance of the sections is observed (usually between 2 and $12 \mathrm{~h}$ ).

(7) After demineralization, rinse the thin-sections in water for 15-30 sec (no longer) to remove the acid, and mount the sections with a coverslip. In no case should sections be allowed to air-dry since this results in the collapse of cell walls. Sections can be mounted directly in a water soluble mounting reagent such as corn syrup (Karo), or dehydrated in an ethanol series and mounted in a standard xylene or alcohol based mounting reagent. Both procedures yield good, but slightly different results. (After a period of one or two weeks, the edges of coverslips mounted in corn syrup should be sealed to prevent crystallization of the mounting medium and the growth of microorganisms.)

\section{DISCUSSION}

The procedures described here are designed to prepare pyrite and limonite permineralizations for study with the light microscope. For an example of results obtained with the pyrite surface-polish technique, see Plate I, 1-2, and for the limonite thin-section technique see Plate I, 3--6.

\section{PLATE I}

1. Iridopteris eriensis Arnold from the Middle Devonian (upper Givetian) of Erie County, New York, U.S.A., transverse section of the type specimen, reprepared. Surfaces of pyrite sections were polished and then etched using concentrated nitric acid for 10 to $30 \mathrm{sec} \times 16$.

2-6. Limonite permineralizations from the Purcell member of the Millboro Shale (Middle Devonian-lower Givetian or upper Eifelian), from Montgomery County, Virginia, U.S.A.

2. Specimen MS-385, a probable member of the Cladoxylopsida, transverse section. This specimen, a mixture of nearly equal parts of pyrite and limonite, was surface polished and etched for 1 to $2 \mathrm{~min}$. using concentrated hydrochloric acid. $\times 33$.

3. Specimen MS-27, Arachnoxylon sp., transverse section. Sections of this specimen were ground thin and demineralized using hydrochloric acid. This section was photographed on a white background with incident light. $\times 16$.

4. Specimen MS-221, also Arachnoxylon sp., longitudinal section. This section was prepared as in 3 , but photographed with transmitted light. The sculptured secondary walls of adjacent tracheids are located at the center and fungal hyphae are observed in each cell lumen. $x 500$.

5. Specimen MS-201, a member of the Aneurophytales (Progymnospermopsida), transverse section. This specimen, prepared as in 3 above but photographed with transmitted light, shows complete continuity of vascular and cortical tissues from the center toward the left. $\times 59$.

6. Specimen MS-42, undetermined but perhaps related to Astralocaulis Hueber, or Stenokoleos bifidus Matten et Banks, transverse section. This view of a section, prepared and photographed as in 5 , shows the contact between primary xylem and primary phloem, and heterogeneous cell types in the region of the primary phloem. $\times 49$. 


\section{PLATE I}
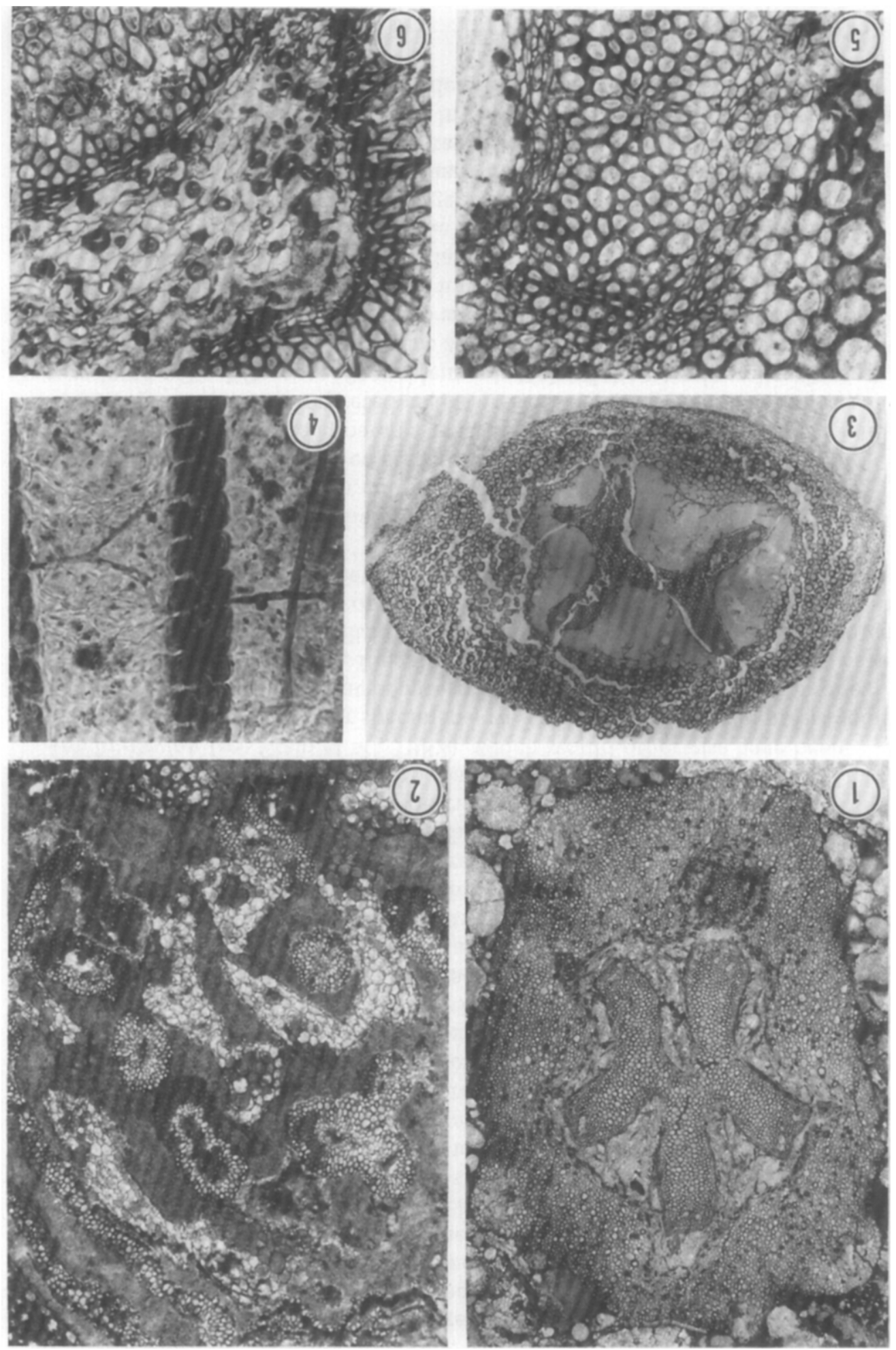
Although we have presented only two general methods of preparation for pyrite or limonite permineralizations, we have found that it is often necessary to vary techniques, sometimes to a great extent, to accommodate special conditions of preservation or special demands imposed by our analysis. One common variant is encountered in specimens comprised of significant quantities of both pyrite and limonite. One specimen, for example, showing nearly equal amounts of the two minerals (Plate I, 2), was prepared using the schedule for pyrite permineralizations except that the sections were etched with concentrated hydrochloric acid instead of nitric acid. Sections of other specimens containing only a small quantity of pyrite, have been ground thin and partially demineralized with hydrochloric acid. These preparations, when placed on a white card and observed with incident light, produce an image which is a combination of transmitted and reflected light. Complete demineralization of these sections with concentrated nitric acid has not proven successful because the acid reacts with the plastic causing it to wrinkle and detach from the surface of the glass slides.

As a major reason for the presentation of this report, we wish to emphasize the fact that the thin-section technique, described above, permits greater resolution of detail from limonite permineralizations than can be obtained from polished or etched surfaces of the same material. The thin-sections have allowed us to make observations on cell wall substructure and detailed analysis of certain tissue regions in plants, such as the "peripheral loop" in Arachnoxylon (see Stein et al., 1982), which would otherwise have been impossible. In several of our specimens, we have also noticed the presence of spherical bodies which might be interpreted as fungal sclerotia, and in one specimen of Arachnoxylon, fungal hyphae within the walls of tracheids have been observed (Plate I, 4). Studies of specimens of this kind have great potential, not only for increasing our knowledge of the life history and subsequent taphonomy of the plants themselves, but also for understanding some of the complexities of the ancient "forest" ecology (including microbial ecology) of which, living and dead, these plants were a part.

With increased resolution, more information can be brought to bear on the interpretation of observed structure. Already we have noticed that profound differences in the apparent structure of cells and tissues, which might otherwise have been interpreted as features of the living plants, are in fact correlated with differences in resident minerals of the permineralizations. A fine example of this is the apparent zonation observed in the cortical tissues of Arachnoxylon (Plate I, 3 at left) and other plants in the Millboro shale of Virginia, discussed in greater depth in another work (Stein et al., 1982). We have also noticed a fine-scale reticulate network in nearly all of our demineralized thin-sections of Millboro shale material. These patterns are similar in scale and generally equivalent in organization to reticulate networks of inferred biological origin in other plant fossils (Hartman and Banks, 1980; Brauer, 1980), but also in some instances interpreted as a preservational artifact (Beck, 1978; Hartman, 1978). In the case of our material, encompassing plants in widely divergent taxonomic groups, the pattern of reticulations we 
see are clearly not of biological origin, but appear instead to be related to the orientations of crystal faces present in the material before demineralization. It is not our purpose here to claim that all reticulate networks are of a non-biologic origin since this would certainly be an inappropriate generalization, but it is clear that some are.

Although the procedures given here were developed for the preparation of permineralizations of pyrite or limonite, it is clear that they have application in nearly every situation where fine-polished surfaces or thin-sections are required, especially in cases where maintaining the structural integrity of sections may be a problem. A recent extension of these methods outside the field of paleobotany has been the preparation of thin-sections, without demineralization, of hydroxyapatite mammal teeth from the Paleocene of western North America (Fisher, 1982) In nearly all applications, we recommend the plastic restabilization step for individual sections as suggested in both procedures given above.

\section{ACKNOWLEDGEMENTS}

The authors wish to express appreciation to Dr. Robert Lowry, Department of Botany, University of Michigan, for much technical help and advice.

Fig.1., in final form, was the work of Derwin Bell, Department of Geological Sciences, University of Michigan. This project was supported by N.S.F. grant \#DEB-78-11165 to Charles B. Beck.

\section{REFERENCES}

Arnold, C.A., 1935. Some new forms and new occurrences of fossil plants from the Middle and Upper Devonian of New York State. Bull. Buffalo Soc. Nat. Sci., $17: 1-12$.

Arnold, C.A., 1940. Structure and relationships of some Middle Devonian plants from western New York. Am. J. Bot., 27: 57-63.

Beck, C.B., 1955. A technique for obtaining polished surfaces of sections of pyritized plant fossils. Bull. Torrey Bot. Club, 82: 286-291.

Beck, C.B., 1957. Tetraxylopteris schmidtii gen. et sp. nov., a probable pteridosperm precursor from the Devonian of New York. Am. J. Bot., 44: 350-367.

Beck, C.B., 1960. The identity of Archaeopteris and Callixylon. Brittonia, 12: 351-368.

Beck, C.B., 1967. Eddya sullivanensis, gen. et sp. nov., a plant of gymnospermic morphology from the Upper Devonian of New York. Palaeontographica, 121B: 1-22.

Beck, C.B., 1971. On the anatomy and morphology of lateral branch systems of Archaeopteris. Am. J. Bot., 58: 758-784.

Beck, C.B., 1978. Periastron reticulatum Unger and Aerocortex kentuckiensis n. gen. et sp., from the New Albany shale of Kentucky. Am. J. Bot., 65: 221-235.

Bonamo, P.M., 1977. Rellimia thomsonii (Progymnospermopsida) from the Middle Devonian of New York State. Am. J. Bot., 64: 1272-1285.

Brauer, D.F., 1980. Barinophyton citrulliforme (Barinophytales incertae sedis, Barinophytaceae) from the Upper Devonian of Pennsylvania. Am. J. Bot., 67: 1186-1206.

Carluccio, L.M., Hueber, F.M. and Banks, H.P., 1966. Archaeopteris macilenta, anatomy and morphology of its frond. Am. J. Bot., 53: 719-730.

Fairon-Demaret, M., 1969. Dixopodoxylon goense (gen. et sp. nov.), a new form genus from the Middle Devonian of Belgium. Bull. Cl. Sci. Acad. R. Belg., 55: 372-386. 
Fairon-Demaret, M., 1977. A new lycophyte cone from the Upper Devonian of Belgium. Palaeontographica, 162B: 51-63.

Fairon-Demaret, M., 1980. A propos des spécimens détermines Protolepidodendron scharianum par Kräusel et Weyland, 1932. Rev. Palaeobot. Palynol., 29: 201-220.

Fisher, D.C., 1982. Crocodilian scatology and the formation of microvertebrate concentrations. Contrib. Mus. Paleontol. Univ. Mich., in press.

Gensel, P.G., 1979. Two Psilophyton species from the lower Devonian of eastern Canada with a discussion of morphological variation within the genus. Palaeontographica, 168B: $81-99$.

Grierson, J.D., 1976. Leclercqia complexa (Lycopsida, Middle Devonian): its anatomy, and the interpretation of pyrite petrifactions. Am. J. Bot., 63: 1184-1202.

Hartman, C.M., 1978. The xylem of Drepanophycus spinaeformis. Bot. Soc. Am. Misc. Ser., 156: 2.

Hartman, C.M. and Banks, H.P., 1980. Pitting in Psilophyton dawsonii, an early Devonian trimerophyte. Am. J. Bot., 67: 400-412.

Jennings, J.R., 1972. A polyvinyl chloride peel technique for iron sulphide petrifactions. J. Paleontol., 46: 70-71.

Kräusel, R. and Weyland, H., 1929. Beiträge zur Kenntnis der Devonflora III. Abh. Senckenb. Naturforsch., 41: 315-360.

Leclercq, S., 1951. Étude morphologique et anatomique d'une fougére du Dévonien supérieur, le Rhacophyton zygopteroides nov. sp. Ann. Soc. Géol Belg. Mem., 9: 1-62.

Leclercq, S., 1957. Étude d'une fructification de Sphenopside á structure conservée du Dévonien supérieur. Acad. R. Belg. Mem., 14: 1-39.

Leclereq, S. and Banks, H.P., 1962. Pseudosporochnus sp. nov, a Middle Devonian plant with cladoxylalean affinities. Palaeontographica, 110B: $1-34$.

Leclercq, S. and Lele, K.M., 1968. Further investigation on the vascular system of Pseudosporochnus nodosus. Palaeontographica, 123B: 97-112.

Matten, L.C., 1966. Improved technique for preparing iron hydroxide plant petrifactions. J. Paleontol., 40: 225-226.

Matten, L.C., 1968. Actinoxylon banksii gen. et sp. nov.: a progymnosperm from the Middle Devonian of New York. Am. J. Bot., 55: 773-782.

Mustafa, H., 1975. Beiträge zur Devonflora I. Argumenta Palaeobot., 4: 101-133.

Mustafa, H., 1978. Beiträge zur Devonflora III. Argumenta Palaeobot., 5: 91-132.

Read, C.B., 1938. Some psilotales from the Hamilton group in western New York. Bull. Torrey Bot. Club, 65: 599-606.

Scheckler, S.E., 1978. Ontogeny of progymnosperms. II. Shoots of Upper Devonian Archaeopteridales. Can. J. Bot., 56: 3136-3170.

Scheckler, S.E. and Banks, H.P., 1971a. Anatomy and relationships of some Devonian progymnosperms from New York. Am. J. Bot., 58: 737-751.

Scheckler, S.E. and Banks, H.P., 1971b. Proteokalon a new genus of progymnosperms from the Devonian of New York State and its bearing on phylogenetic trends in the group. Am. J. Bot., 58: 874-884.

Serlin, B.S. and Banks, H.P., 1978. Morphology and anatomy of Aneurophyton, a progymnosperm from the late Devonian of New York. Palaeontogr. Am., 8: 343-359.

Skog, J.E. and Banks, H.P., 1973. Ibyka amphikoma gen. et sp. n., a new protoarticulate precursor from the late Middle Devonian of New York State. Am. J. Bot., 60: 366380 .

Stein, W.E., Jr., 1981. Reinvestigation of Arachnoxylon kopfii from the Middle Devonian of New York State, U.S.A. Palaeontographica, 177B: 90-117.

Stein, W.E., Jr., Wight, D.C. and Beck, C.B., 1982. A new species of Arachnoxylon from the Middle Devonian of Virginia. Bot. Gaz., in press.

Stockmans, F., 1968. Végêtaux Mésodévoniens récoltés aux confins du massif du Brabant (Belgique). Inst. R. Sci. Nat. Belg. Mem., 159: 1-49. 